\title{
Butylscopolamine Bromide
}

National Cancer Institute

\section{Source}

National Cancer Institute. Butylscopolamine Bromide. NCI Thesaurus. Code C65277.

An orally available bromide salt form of butylscopolamine, a quaternary ammonium derivative of the alkaloid scopolamine, with anticholinergic property. Upon oral administration, hyoscine butylbromide binds to and blocks muscarinic receptors located on postgang lionic parasympathetic nerve endings and on smooth muscle cells. This blocks the activity of acetylcholine (Ach) and causes its antispasmodic effect in the gastrointestinal (Gl), urinary, uterine, and biliary tracts. This agent may also facilitate radiologic visualization of the Gl tract. 